\title{
Study on Ideological and Political Education in Universities from the Perspective of "China Dream"
}

\section{Pin Lv \\ Chongqing University of Education, 400067 Chongqing}

\begin{abstract}
China Dream is the common ideal of all the Chinese people to achieve the great rejuvenation of China, and is also extension and innovation of universities ideological and political education contents. In this study, we analyze the current troubles of universities ideological and political education, and then probe the values of China Dream in ideological and political education. At last based on this, we propose some political education strategies around China Dream.
\end{abstract}

KEYWORDS:China Dream; Ideological and Political Education; Political Faith

\section{Introduction}

China Dream is an important guiding ideology and important concept of governance proposed by president Xi Jinping, since the 18th National Congress of the Communist Party of China. China Dream is interpreted as a dream to realize the great rejuvenation of China. Contemporary college students are the builders and successors of the socialist Chinese characteristics, and are also the backbones to realize China Dream. The current ideological and political education of vocational colleges is facing many difficulties, so how to mine the value of China Dream for ideological and political education, and promote the reform of the ideological and political education, is an issue worth considering in our ideological and political education of higher vocational colleges.

\section{Troubles of Ideological and Political Education}

\section{A. Students Lack of Political Awareness}

Someundergraduates have deviation in ideology and social values, lack of knowledge and belief in communism and social responsibility. In terms of political education, many college students pay little attention to national policy and social situation, neglect to participate in any political activity. They tend to be more concerned about personal development, rather than the country's future and development direction

\section{B. Weak Systematicness of Political Theory Course}

The ideological and political theory course in universities universally lack of firmness and continuity. Although college education encourages students self-learning and innovation, the guiding role of teachers in theory courses teaching is very important. In the teaching of ideological and political course, teachers should not be just echo what the books say, but should explain profound theories in simple language to explain, guide and inspire students, so that guide students to understand the Marx doctrine and the more abstract theory. This requiresthat the ideological and political course be more perfect and systematic, and at the same time, teachers must first have a certain awareness and understanding of political theories. Only based on this can cultivate 
students' good political qualities and shape their correct values.

\section{The Impact of Internet}

The traditional way of Ideological and political education in universities mainly includes Political programs, group learning activities, theme education, etc. These educational activities play a certain role of in college ideological and political education. However, in today's Internet age, diversified information is profoundly affecting university student's thought. Some online activists and conspirators attempt to create public opinion tendency, and deliberately fabricate and spread false information through the network. Due to the lack of social experience and proven judgment, the students may easily be induced by these bad thoughts, forming political bias. So we can say that,

\section{Values of China Dream in Ideological and Political Education}

\section{A. Establish a Firm Political Faith}

Youth talent is the first resource to promote the country's development, while faith is the source of power to stimulate their struggle. College students nowadays generally lack of political faith. Achieving national prosperity, national rejuvenation and building a socialism with Chinese characteristics is the goal of China Dream, containing a strong political ideas and political ideals. As a kind of value pursuit, it requests the people to have higher values and political beliefs. Regarding China Dreamas an opportunity, universities conducting in-depth development of ideological and political education can help college students to establish the correct values, moral values and the lofty political beliefs.

\section{B. Arouse Collective Sense of Honor}

Modern China was once reduced to a semi colonial and semi feudal society, since then to realize national rejuvenation became a common pursuit dream of the countrymen. Today in the new era, China Dream is endowed with new connotation for the national dream, thatis, people across the country unite together, and strive for the construction of an prosperous, democratic, civilized and harmonious, modern country.China Dream adheres to promote patriotism as the core, inspiring students' patriotism and national consciousness, to convene students to plunge in China's socialist modernization with full fighting spirit. China Dream cannot be achieved solely by individuals, but it requires the joint efforts of all the national people.China Dream helps strengthen the students' collectivist values education, for it requires students to clarify the relationship between state, collective and individual.

\section{Promote Political Education Resource \\ Development}

Educational resources refer to the sum of all available resources for education services. To some extent, implementation effect of ideological and political education depends on the amount of the ideological and political education resources. China Dream being proposed, many scholars have made in-depth study of its main content, meaning and characteristics of the times. The thinking product brought by China Dream is available resources for college ideological and political education, becoming became an important ideological and political theory course content. In addition, along with the ideologicaldiscussions wave of China Dream, many universities have organized China Dream related theme activities. These activities calls 
for college students to learn China Dream, and innovates the form, content and carrier of universities ideological and political education, and then develop richer ideological and political education resources.

\section{China Dream Political Education Strategies}

\section{A. Integrate China Dream into Political Curriculum System}

The task of university ideological and political theory course is to conduct a systematic education in Marxist theory, to help students establish correct outlook of world, life and value. Integrate China Dream into university political curriculum system, deeply interpreting the connotation, basic characteristics and significance of China Dream, and objectively analyze the current reality road to realize China Dream. Cultivate students' spirit of patriotism and collective sense of honor, closely linking the nation fate and individual destiny. In order to better integrate China Dream into university ideological and political theory course, we need to grab every fusion point of Ideological and political theory course and China Dream. For example, in the course "basic principles of Marxism", when it comes to "people's role in the social development", we can integrate president $\mathrm{Xi}$ Jinping's view“'China Dream is people's dream after all, so it must closely rely on the people to achieve, and must continue to benefit for people"; when it comes to "scientific connotation of socialism with Chinese characteristics", we can integrate basic connotation and characteristics of China Dream; in the course "ideological moral cultivation and legal foundation", we can integrate China Dream into patriotism education, to enhance students' sense of social responsibility and historic mission, commonly struggling to realize the great rejuvenation of the Chinese nation.

\section{B. Organize China Dream CampusTheme Activities}

Campus culture as the main carrier of education plays a role of university students' personality shaping, behavior restriction and value guidance, etc. The construction of campus culture is one important part of Ideological and political education in Universities, and is an important way to improve college students' Ideological and political idea and comprehensive quality. To strengthen the construction of campus culture depends on spread and popularization of China Dream on campus. Based on the carrier function of campus culture, vigorously organizing China Dream special publicity activitiesis not only conducive to the construction of campus culture in colleges and universities, but also conducive to Publicity and flourish of China Dream. What's more important, by conducting the rich cultural activities on campus attract college students to participate in the activities, allowing students to accept the ideological and political education imperceptibly.

University should encourage student organizations to launch group learning activities of China Dream theme, and focus on supporting some activities of interesting content and new forms, to form a certain influence and organizational size within the campus. The activities form can be thematic essay contest, inspirational movie show, keynote speech contest and so on, to express the understanding and pursuit of China Dream in the forms of words, songs, movies, shows, etc.

\section{Build China Dream Social Practice Education Platform}

University ideological and political education should pay particular attention to the combination of theory and practice. By building China Dream social practice education platform, 
allow students to exercise their perseverance and character in social practice. Through practice, students will deeply understand the essence of Deng Xiaoping Theory and "Three Represents" Important Thought, and improve perceptions of the party's policy guidelines. Universities should make full use of social resources, to build a China Dream social practice platform, and organize related practice activities in cooperation with various types of organizations. Universities can organize activities such as summer student's social practice, "Dream China" volunteer action plan, etc.

Through participation in social practice activities, university students have a chance at the grass-roots level in the countryside, and make in-depth communication with the majority of the people, to touch the dreams of ordinary people. Only in this way can achieve the good effect of college students' ideological and political education. In the activities, students can also grasp history and current situation of China, and then feel the great achievements of reform and opening up policy.

\section{Establish China Dream Education}

\section{Guarantee System}

To play the role of China Dream in universities ideological and political education, the key is to establish China Dream education guarantee system. First, establish the leadership mechanism, carrying out the working mechanism of leadership to lead, each department to follow up and teachers and students to participate in. Second, establish the fundsguarantee mechanism. It needs to plan for adequate funding to implement and promote the work of ideological and political education, so an effective fundsguarantee mechanism is required. Third, establishthe assessment and evaluation mechanism, by construction of evaluation system for China Dream of Ideological and political education, to realize the scientific ideological and political education work. Finally, establish the inspection and supervision mechanism, being responsible by a dedicated team, to timely follow up and examine the progress and result of ideological and political education tasks.

\section{Conclusion}

development of the internet has caused some impact on the traditional ideological education in universities.

To integrate China Dream into ideological and political theory curriculum system, we also need to change the pastteaching methods and course content, to explore the new teaching mode, so that university ideological and political theory course would be more systematic and scientific.

\section{REFERENCE:}

[1] Studwell J. The China dream: The quest for the last great untapped market on earth[M]. Grove Press, 2003.

[2] Xiaoming Z. China Dream: A New Chinese Way in International Society?[J]. China's Many Dreams: Comparative Perspectives on China's Search for National Rejuvenation, 2014: 226.

[3] Osnos E. Can China Deliver The China Dream (s)?[J]. The New Yorker, 2013, 26.

[4] Frazer E. Introduction: the idea of political education[J]. 1999.

[5] Price R F. Marx and education in Russia and China[M]. Routledge, 2011.

[6] Wang Z. Not Rising, But Rejuvenating: The “Chinese Dream"[J]. 2013. 